\title{
SISTEM INFORMASI PENDATAAN SURAT MASUK DAN KELUAR CV. MEDIA KREATIF ONLINE
}

\author{
Rona Tanjung \\ Sekolah Tinggi Manajemen Informatika dan Komputer GICI \\ Komp. Batu Aji Center Park - Simpang Base Camp Telp. 0778391333 Fax 0778394 641, Kota Batam \\ Propinsi Kepulauan Riau, Indonesia \\ email: rona_rusty@yahoo.co.id
}

\begin{abstract}
Berdasarkan hasil analisis yang telah dilakukan di CV. Media Kreatif Online, bahwa sistem Pendataan Surat masuk dan surat keluar,masih melakukan sistem manual atau Tulisan Sehingga dalam proses pengelolahan data Surat Kelurahan mengalami kesulitan, yaitu tidak efisin, tidak akurat dan tidak cepat. Pada tugas akhir ini penulis memilih judul "Sistem informasi pendataan surat masuk dan kemuar CV. Media Kreatif Online". Adapun beberapa tahapan metode pengumpulan data yang digunakan yakni observasi, wawancara dan penelitian kepustakaan.Sistem informasi yang digunakan yakni sistem pemrograman visual basic 8.0 merupakan IDE (Integrated Development Environment) yang digunakan untuk dikembangkan software dalam IDE inilah yang tersedia berbagai fitur yang memudahkan pemrograman, seperti kompilasi, pengaturan projek, mengedit antar muka secara visual yang dirancang menjadi suatu sistem untuk mempermudah dan mempercepat proses pengolahan pendataan Surat masuk dan surat keluar
\end{abstract}

Kata Kunci: Sistem Informasi pendataan surat masuk dan surat keluar

\section{PENDAHULUAN}

$\begin{array}{rrr}\text { Pada era } & \text { globalisasi } & \text { saat ini } \\ \text { perkembangan } & \text { teknologi } & \text { sangat }\end{array}$ diperlukan demi upaya peningkatan efesien dan efektifitas suatu pekerjaan. Perkembangan teknologi semakin canggih menuntut manusia untuk dapat beradaptasi dan menyesuaikan diri dengan perkembangan tersebut. Salah satu faktor yang mendukung adanya suatu teknologi dalam sistem dalam pengolahan data yang akurat, yang nantinya dapat memberikan sebuah informasi dan data perusahaan, maupun dari pihak internal dan external yang membutuhkan agar fungsi dan kinerja perusahaan maupun organisasi dapat berjalan dengan baik.
CV. Media Kreatif Online adalah tempat usaha yang bergerak dalam bidang travel Pada saat ini sistem yang digunakan pada CV. Media Kreatif Online sudah menggunakan sistem komputer. Tetapi untuk menangani surat masuk dan surat keluar belum menggunakan sistem komputer sebagai alat bantu. Untuk menginputkan suatu data terutama pendataan maupun sistem informasi surat masuk dan surat keluar pada CV. Media Kratif Online meskipun telah memiliki fasilitas komputer. Banyaknya surat yang masuk maupun surat yang keluar yang diterima dan dikirim oleh CV. Media Kreatif Online dan cara pendataan surat yang masuk dan keluar masih
JURSIMA

Jurnal Sistem Informasi dan Manajemen https://ejournal.giciku.ac.id/ STMIK GICl 
menggunakan buku besar atau disposisi. Hal ini kurang efektif, mengingat staf bagian tata usaha harus mencatat surat yang masuk dan surat yang keluar sehingga menyebabkan terjadinya kesalahan dalam pencatatan nomor maupun kode surat yang akan keluar maupun kode surat yang masuk. Untuk menghindari terjadinya kekeliruan maupun kesalahan dalam pendataan surat yang masuk dan surat yang keluar, maka perlu mengganti atau mengubah sistem yang lama menjadi sistem yang baru dengan memamfaatkan fasilitas komputer yang ada di kantor tersebut demi menunjang pekerjaan agar lebih cepat diselesaikan dan mengurangi tingkat kesalahan yang dibuat.

Adapun tujuan dilakukan suatu penelitian yang bertujuan untuk ,sebagai berikut:

1. Unutk mengetahui prosedur pendataan surat masuk dan surat keluar pada CV. Media Kreatif Online

2. Untuk menyelesaikan masalah masalah yang ditemui dalam pendataan surat masuk dan surat keluar pada CV. Media Kreatif Online.

3. Untuk merancangan sistem informasi pendataan surat masuk dan surat keluar pada CV. Media Kreatif Online menggunakan bahasa pemograman Microsoft Visual basic. Net 2008.

\section{Metode Penelitian}

observasi, wawancara dan penelitian kepustakaan.Sistem informasi yang digunakan yakni sistem pemrograman visual basic 8.0 merupakan IDE (Integrated Development Environment) yang digunakan untuk dikembangkan software dalam IDE inilah yang tersedia berbagai fitur yang memudahkan pemrograman, seperti kompilasi, pengaturan projek, mengedit antar muka secara visual yang dirancang menjadi suatu sistem untuk mempermudah dan mempercepat proses pengolahan pendataan Surat masuk dan surat keluar

\section{Hasil dan Pembahasan}

\section{Analisa Sistem Yang Sedang Berjalan}

Analisa sistem yang sedang berjalan merupakan pengkajian dan penentuan dari sistem yang sedang berjalan atau sistem lama untuk mempermudah dalam mendefenisikan permasalahan atau kendala-kendala yang terjadi pada CV. Media Kreatif Online Berdasarkan dari hasil pengamatan langsung pada CV. Media Kreatif Online sistem yang sedang berjalan pada CV. Media Kreatif Online belum menggunakan sistem komputerisasi terutama dalam informasi pendataan surat masuk dan surat keluar yang masih menggunakan sistem manualisasi. Dengan demikian sistem yang lama akan dirancang menjadi sistem yang baru dengan menggunakan perangkat lunak Microsoft Visual Studio 2008 yang bertujuan untuk mempermudah dalam pengolahan pendataan surat masuk dan surat keluar.

Sistem pengolahan data pada CV. Media Kratif Online sampai saat ini masih menggunakan dengan cara penulisan dan kemungkinan dapat terjadi kesalahan dalam penulisan data surat masuk dan data surat keluar karena belum mempunyai aplikasi khusus untuk melakukan pengolahan data surat masuk dan surat keluar serta pendataan surat masuk dan surat keluar.
JURSIMA

Jurnal Sistem Informasi dan Manajemen https://ejournal.giciku.ac.id/ STMIK GICl 
Adapun bentuk sistem yang sedang berjalan pada CV. Media Kreatif Online dalam pendataan surat masuk adalah :

1. Penyalur surat memberikan bukti penerimaan surat kepada sekretaris.

2. Sekretaris menerima bukti penerimaan surat dari pengirim dan menandatangani bukti penerimaan surat, serta mengembalikan bukti penerimaan surat yang sudah ditanda tangani kepada penyalur surat.

3. Penyalur surat menerima bukti penerimaan surat dan memberikan surat ke sekretaris.

4. Sekretaris menerima surat dari penyalur dan mendata surat tersebut serta mencatatnya kedalam pendataan surat masuk dan membuat laporannya dan memberikan laporannya kepada kepala lurah.

Adapun bentuk sistem yang sedang berjalan pada CV. Media Kraetif Online dalam pendataan surat keluar adalah :

1. Staff Admin membuat surat keluar dan memberikan kepada kepala lurah untuk ditandatangani.

2. Setelah surat keluar ditanda tangani maka sekretaris mencatat surat keluar kedalam pendataan surat keluar dan membuat laporan surat keluar untuk diserahkan kepada kepala Pimpinan.

Setelah mencatat maka sekretaris memberikan surat keluar kepada penyalur surat untuk diantarkan kepada pihak yang akan menerima surat tersebut.

Bentuk dokumen input yang digunakan oleh CV. Media Kreatif Online sebagai dasar pengolahan data surat masuk dan surat keluar adalah berupa formulir pendataan surat masuk dan surat keluar yang di isi pada saat mendata surat masuk dan surat keluar dilakukan. Bentuk formulir input tersebut dapat dilihat pada gambar seperti berikut ini:

\section{Analisa Kelemahan Sistem yang Sedang Berjalan}

Adapun kelemahan sistem yang sedang berjalan pada CV. Media Kreatif Online adalah sebagai berikut :

1. Dalam proses pencarian data surat masuk dan surat keluar masih sulit untuk dilakukan karena harus membutuhkan waktu yang cukup lama.

2. Dapat terjadi kesalahan pada proses pembuatan laporan karena laporan dibuat dalam bentuk tabel Microsoft Word.

3. Adanya kesamaan data surat masuk dan surat keuar yang satu dengan surat-surat yang lainnya.

\section{Ulasan Sistem Baru}

Dengan adanya sistem baru yang diusulkan merupakan perbaikan dari sistem aplikasi dalam bentuk buku manual menjadi sistem yang terkomputerisasi dengan aplikasi yang dirancang khusus untuk pendatan surat masuk dan surat keluar, sehingga penyajian informasi atau laporan yang dihasilkan sistem baru akan lebih efektif dan efisien dalam pemrosesan penginputan data, penyimpanan dan pencarian data. Jadi sistem informasi yang dirancang ini nantinya dapat digunakan untuk mengatasi kekurangan dan keterlambatan informasi yang dihasilkan pada CV. Media Kreatif Online.

Berikut ini adalah beberapa sasaran yang akan dicapai pada rancangan sistem baru, yaitu :

1. Membantu pihak yang terkait dalam melaksanakan tugasnya masing-
JURSIMA

Jurnal Sistem Informasi dan Manajemen https://ejournal.giciku.ac.id/ STMIK GICl 


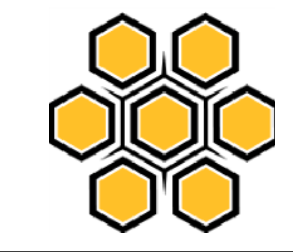

masing, terutama pada bagian sekretaris dalam membuat data surat masuk dan surat keluar.

2. Mempercepat proses pembuatan laporan

3. Memberikan informasi pendataan surat masuk dan surat keluar dalam waktu yang relatif singkat

\section{Data Flow Diagram}

Data flow diagram digunakan untuk menjelaskan tentang aliran data dan proses aplikasi yang digunakan. Alat bantu yang digunakan pada perancangan sistem yang baru berikut ini menggunakan diagram konteks dan DFD level 0, level 1 dan seterusnya. Dalam sistem ini penulis mencoba menggambarkan diagram konteks, DFD level 0, dengan menggunakan diagram alir dapat dipahami bagaimana sistem tersebut berjalan.

Diagram ini digunakan untuk menggambarkan sumber serta tujuan data yang akan di proses atau dengan kata lain digaram tersebut digunakan untuk menggambarkan sistem secara keseluruhan/global dari keseluruhan sistem yang ada. Bentuk diagram konteks dari sistem informasi pendataan surat masuk dan surat keluar pada CV. Media Kreatif Online dapat dilihat pada gambar berikut ini :

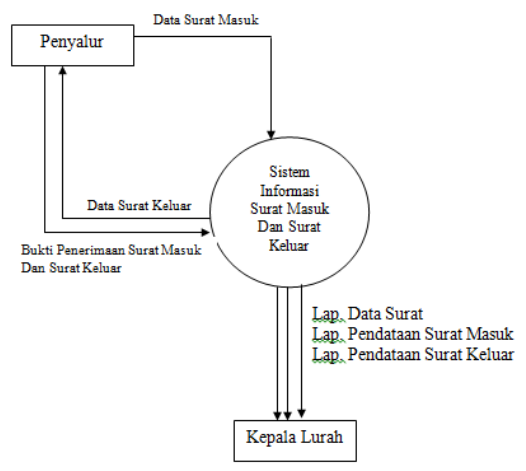

Sistem informasi ini menghasilkan output berupa laporan-laporan yang dibutuhkan oleh kepala dinas yang ada pada CV. Media Kratif Online, yang nantinya dapat dipergunakan sebagai bahan pengambilan keputusan dalam pendataan surat masuk dan surat keluar tersebut.

Adapun bentuk laporan yang dirancang adalah sebagai berikut :

\section{Laporan Data Surat}

Tujuan dari laporan ini adalah untuk mengetehaui data surat yang tersedia pada CV. Media Kratif Online. Adapun tampilan dari laporan data surat dapat dilihat pada table di bawah ini :

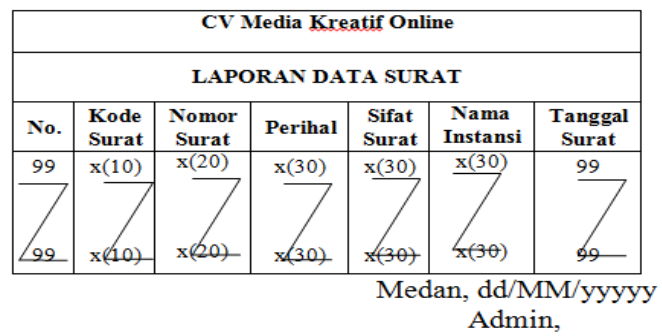

2. Laporan Pendataan Surat Masuk Perhari
JURSIMA

Jurnal Sistem Informasi dan Manajemen https://ejournal.giciku.ac.id/ STMIK GICl 
Tujuan dari laporan ini adalah untuk mengetehaui pendataan surat masuk perhari yang pernah melakukan pendataan surat masuk perhari pada CV. MEDIA KREATIF ONLINE. Adapun tampilan dari laporan pendataan surat masuk perhari dapat dilihat pada Tabel seperti berikut:

\begin{tabular}{|c|c|c|c|c|}
\hline \multicolumn{5}{|c|}{ CV. Media Kreatif Online } \\
LAPORAN PENDATAAN SURAT \\
MASUK PERHARI \\
\hline No. & $\begin{array}{c}\text { Kode } \\
\text { Surat }\end{array}$ & Tanggal & $\begin{array}{c}\text { Nomor } \\
\text { Surat }\end{array}$ & $\begin{array}{c}\text { Nama } \\
\text { Instansi }\end{array}$ \\
\hline 99 & $\mathrm{x}(10)$ & 99 & 99 & x(30) \\
\hline Tanggal : dd/mm/yyyy & & & \\
\hline 99 & $\mathrm{x}(10)$ & 99 & 99 & x(30) \\
\hline \multicolumn{5}{|c|}{$\begin{array}{c}\text { Batam, } \\
\text { dd/MM/yyyy } \\
\text { Admin, }\end{array}$} \\
\hline
\end{tabular}

JURSIMA

Jurnal Sistem Informasi dan Manajemen
3. Laporan Pendataan Surat Masuk Perbulan

Tujuan dari laporan ini adalah untuk mengetehaui pendataan surat masuk perbulan yang pernah melakukan pendataan CV.Media Kreatif Online Adapun tampilan dari laporan pendataan

\begin{tabular}{|c|c|c|c|c|}
\hline \multicolumn{5}{|c|}{ CV. Media Kreatif Online } \\
LAPORAN PENDATAAN SURAT \\
MASUK PERTAHUN
\end{tabular}

surat masuk perbulan dapat dilihat pada seperti berikut:

\begin{tabular}{|c|c|c|c|c|}
\hline \multicolumn{5}{|c|}{ CV. Media Kreatif Online } \\
LAPORAN PENDATAAN SURAT \\
MASUK PERBULAN \\
Bulan : mm/yyyy \\
\hline No. & $\begin{array}{c}\text { Kode } \\
\text { Surat }\end{array}$ & Tanggal & $\begin{array}{c}\text { Nomor } \\
\text { Surat }\end{array}$ & $\begin{array}{c}\text { Nama } \\
\text { Instansi }\end{array}$ \\
\hline 99 & x(10) & 99 & 99 & x(30) \\
99 & x(10) & 99 & 99 & x(30) \\
\hline
\end{tabular}

Batam,
dd/MM/yyyyy

Admin, 


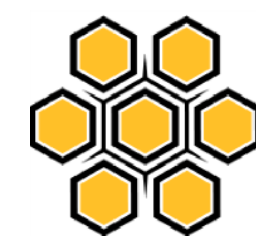

4. Laporan Pendataan Surat Masuk Pertahun

Tujuan dari laporan ini adalah untuk mengetehaui pendataan surat masuk pertahun yang pernah melakukan pendataan surat masuk perhari pada $\mathrm{CV}$. Media Kreatif Online. Adapun tampilan dari laporan pendataan surat masuk pertahun dapat dilihat pada

5. Laporan Pendataan Surat Keluar Perhari

Tujuan dari laporan ini adalah untuk mengetehaui pendataan surat keluar perhari yang pernah melakukan pendataan surat keluar perhari pada CV. MEDIA KREATIF ONLINE. Adapun tampilan dari laporan pendataan surat keluar perhari dapat dilihat pada seperti berikut:

\begin{tabular}{|c|c|c|c|c|}
\hline \multicolumn{5}{|c|}{$\begin{array}{l}\text { CV. MEDIA KREATIF ONLINE } \\
\text { LAPORAN PENDATAAN SURAT } \\
\text { KELUAR PERHARI }\end{array}$} \\
\hline \multicolumn{5}{|c|}{ Tanggal : dd/mm/yyyy } \\
\hline $\begin{array}{c}\text { No } \\
\cdot\end{array}$ & $\begin{array}{c}\text { Kode } \\
\text { Sura } \\
\mathbf{t}\end{array}$ & $\begin{array}{c}\text { Tangga } \\
l\end{array}$ & $\begin{array}{l}\text { Nomo } \\
\text { r } \\
\text { Surat }\end{array}$ & $\begin{array}{l}\text { Nama } \\
\text { Instans } \\
\text { i }\end{array}$ \\
\hline 99 & $x(10)$ & 99 & 99 & $x(30)$ \\
\hline 99 & $x(10)$ & 99 & 99 & $x(30)$ \\
\hline
\end{tabular}

JURSIMA

Jurnal Sistem Informasi dan Manajemen

\section{MEDIA KREATIF ONLINE LAPORAN PENDATAAN SURAT KELUAR PERTAHUN}

Tahun : yyyy

\begin{tabular}{|l|c|c|c|c|}
\hline No. & $\begin{array}{c}\text { Kode } \\
\text { Surat }\end{array}$ & Tanggal & $\begin{array}{c}\text { Nomor } \\
\text { Surat }\end{array}$ & $\begin{array}{c}\text { Nama } \\
\text { Instansi }\end{array}$ \\
\hline 99 & $\mathrm{x}(10)$ & 99 & 99 & $\mathrm{x}(30)$ \\
99 & $\mathrm{x}(10)$ & & 99 & $\mathrm{x}(30)$ \\
\hline
\end{tabular}

Tujuan dari laporan ini adalah untuk mengetehaui pendataan surat keluar pertahun yang pernah melakukan pendataan surat keluar pertahun pada $\mathrm{CV}$. MEDIA KREATIF ONLINE. Adapun tampilan dari laporan pendataan surat keluar pertahun

\section{Perancangan Input}

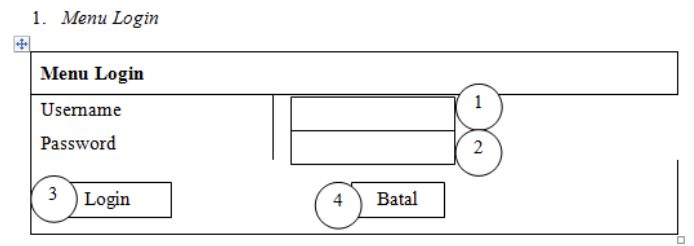

Menu Login

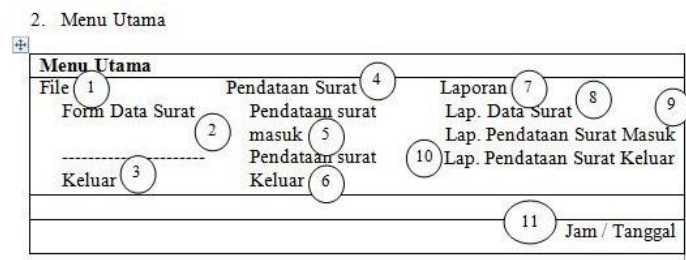

Gambar 4.9 Desain Menu Utama

1. Menu Utama

2. Mепи File bersikan tentang form data surat dan menu keluar 
3. Menu Pendataan surat berfungsi untuk menampilkan form pendataan surat masuk dan keluar

4. Мепu Laporan bersikan tentang laporan data surat, laporan pendataan surat masuk dan laporan pendataan surat keluar

5. Submenu laporan data surat berfungsi untuk menampilkan laporan data surat

6. Submenu laporan pendataan surat masuk berfungsi untuk menampilkan laporan pendataan surat masuk perhari, perbulan dan pertahun

7. Submenu laporan pendatan surat kelua berisikan tentang laporan pendataan surat keluar perhari, perbulan dan pertahun.

\section{Input Data surat}

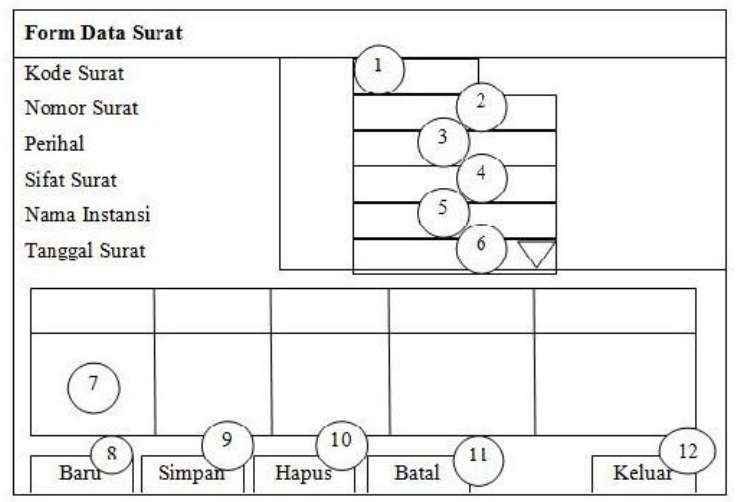

Keterangan :

1. TextBox Kode surat, untuk mengisikan kode surat

2. TextBox Nomor Surat, untuk mengisikan nomor surat

3. TextBox Perihal, untuk mengisikan perihal surat

4. TextBox Sifat Surat, untuk mengisikan sifat surat

5. TextBox Nama Instansi, untuk mengisikan nama instansi
6. Datetime picker Tanggal surat, untuk mengisikan tanggal surat

7. ListView LV, untuk menampil daftar dta surat yang telah disimpan ke dalam database

8. Button Baru, berfungsi untuk membuat data baru

9. Button Simpan, berfungsi untuk menyimpan data kamar ke dalam database secara permanen

10. Button Hapus, berfungsi untuk menghapus data secara permanen ke dalam database

11. Button Batal, berfungsi untuk membatalkan proses yang sedang berlangsung yang akan kembali kepada tampilan awal form nya

12. Button Keluar, berfungsi untuk keluar dari form data surat

\section{Input Data Pendataan Surat Masuk}

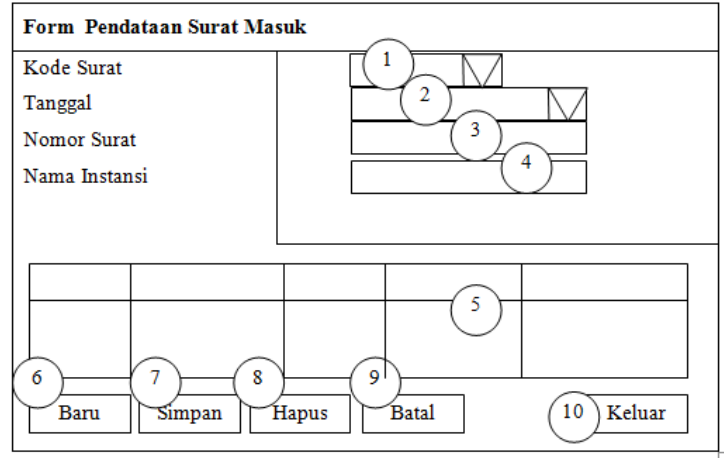

Keterangan :

1. TextBox Kode Surat, untuk mengisikan kode surat

2. DateTime Picker Tanggal, untuk mengisikan tanggal

3. TextBox Nomor surat, untuk mengisikan nomor surat

4. TextBox Nama Instansi, untuk mengisikan nama Instansi

5. ListView LV, untuk menampil data surat masuk yang telah disimpan ke dalam database
JURSIMA

Jurnal Sistem Informasi dan Manajemen https://ejournal.giciku.ac.id/ STMIK GICl 
6. Button Baru, berfungsi untuk membuat data baru

7. Button Simpan, berfungsi untuk menyimpan data ke dalam database

8. Button Hapus, berfungsi untuk menghapus data secara permanen ke dalam database

9. Button Batal, berfungsi untuk membatalkan proses yang sedang berlangsung

10. Button Keluar, berfungsi untuk keluar dari form pendataan surat masuk

\section{Input Data Pendataan Surat Keluar}

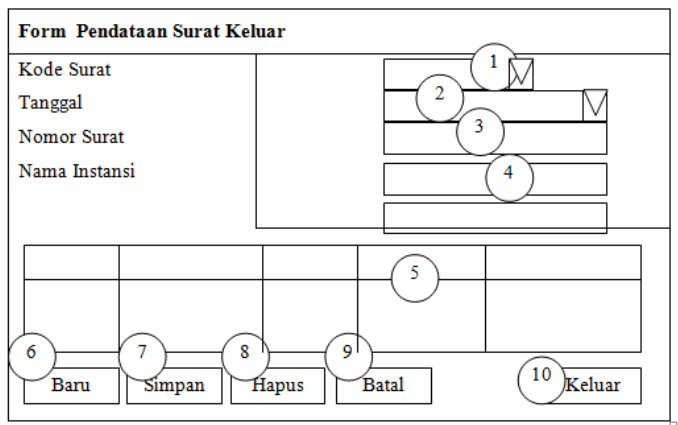

TextBox Kode Surat, untuk mengisikan kode surat

1. DateTime Picker Tanggal, untuk mengisikan tanggal

2. TextBox Nomor surat, untuk mengisikan nomor surat

3. TextBox Nama Instansi, untuk mengisikan nama Instansi

4. ListView LV, untuk menampil data surat masuk yang telah disimpan ke dalam database

5. Button Baru, berfungsi untuk membuat data baru

6. Button Simpan, berfungsi untuk menyimpan data ke dalam database

7. Button Hapus, berfungsi untuk menghapus data secara permanen ke dalam database
8. Button Batal, berfungsi untuk membatalkan proses yang sedang berlangsung

9. Button Keluar, berfungsi untuk keluar dari form pendataan surat keluar

\section{Perancangan Tabel}

Dalam merancang suatu sistem yang baik dibutuhkan tabel yang bertujuan untuk memudahkan pengambilan informasi pengolahan data serta dalam pembuatan laporan. Tabel tersebut akan saling berhubungan satu sama lainnya dan dapat digunakan sesuai dengan kebutuhan pemakai dan bertujuan mempermudah dalam pembuatan sistem nantinya

Tabel yang dibutuhkan yaitu

1. Tabel Surat

\begin{tabular}{|c|c|c|c|c|c|}
\hline \multicolumn{2}{|c|}{$\begin{array}{l}\text { Nama Database } \\
\text { Nama Tabel } \\
\text { Field Kunci }\end{array}$} & \multicolumn{4}{|c|}{$\begin{array}{l}\text { dbsuratmasuk_suratkeluar } \\
\text { Surat } \\
\text { Kode_Surat }\end{array}$} \\
\hline No & \multicolumn{2}{|c|}{ Nama Field } & Tipe Data & Panjang & Keterangan \\
\hline 1. & \multicolumn{2}{|c|}{ Kode_Surat } & Varchar & 10 & Kode Surat \\
\hline 2. & \multicolumn{2}{|c|}{ Nomor_Surat } & Varchar & 30 & Nomor Surat \\
\hline 3. & \multicolumn{2}{|l|}{ Perihal } & Varchar & 30 & Perihal \\
\hline 4. & \multicolumn{2}{|c|}{ Sifat Surat } & Varchar & 10 & Sifat Surat \\
\hline 5. & \multicolumn{2}{|c|}{ Nama_Instansi } & Varchar & 30 & Nama Instansi \\
\hline 6. & \multicolumn{2}{|c|}{ Tanggal_Surat } & Date & & Tanggal Surat \\
\hline
\end{tabular}

2. Tabel Surat Masuk

Tabel surat masuk berfungsi untuk menampung semua data surat masuk yang telah diinput, berikut dapat dilihat pada tabel seperti berikut ini:

\begin{tabular}{|c|c|c|c|c|c|}
\hline \multicolumn{2}{|c|}{$\begin{array}{l}\text { Nama Database } \\
\text { Nama Tabel } \\
\text { Field Kunci }\end{array}$} & \multicolumn{4}{|c|}{$\begin{array}{l}\text { dbsuratmasuk_suratkeluar } \\
\text { SuratMasuk } \\
\text { : Id }\end{array}$} \\
\hline No & \multicolumn{2}{|c|}{ Nama Field } & Tipe Data & Panjang & Keterangan \\
\hline 1. & \multicolumn{2}{|l|}{ Id } & Int & & Id Surat Masuk \\
\hline 2. & \multicolumn{2}{|l|}{ Tanggal } & Date & & Tanggal \\
\hline 3. & \multicolumn{2}{|c|}{ Kode_Surat } & Varchar & 10 & Kode Surat \\
\hline
\end{tabular}

\section{Tabel Surat Keluar}

Tabel surat keluar berfungsi untuk menampung semua data surat keluar yang telah diinput, berikut dapat dilihat pada tabel seperti berikut ini: 


\begin{tabular}{|c|c|c|c|c|c|}
\hline \multicolumn{2}{|c|}{$\begin{array}{l}\text { Nama Database } \\
\text { Nama Tabel } \\
\text { Field Kunci }\end{array}$} & \multicolumn{4}{|c|}{$\begin{array}{l}\text { dbsuratmasuk_suratkeluar } \\
\text { SuratKeluat } \\
\text { : Id }\end{array}$} \\
\hline No & \multicolumn{2}{|c|}{ Nama Field } & Tipe Data & Panjang & Keterangan \\
\hline 1. & \multicolumn{2}{|l|}{ Id } & Int & & Id Surat Keluar \\
\hline 2. & \multicolumn{2}{|c|}{ Tanggal } & Date & & Tanggal \\
\hline 3. & \multicolumn{2}{|c|}{ Kode_Surat } & Varchar & 10 & Kode_Surat \\
\hline
\end{tabular}

\section{Tabel Relasi}

Tabel relasi merupakan alat bantu perancangan database yang berguna untuk menggambarkan hubungan antara tabletabel yang agar memberikan kemudahan dalam pembuatan tabel relasi atau hubungan antara tabel satu dengan tabel yang lainnya sesuai dengan tabel yang telah dibuat, adapun relasi antar table pada database yang telah dirancang ini bertujuan untuk memberikan kemudahan dalam pembuatan hubungan tabel dan dalam pemberian informasi yang baik dan benar, hubungan tabel atau relasi tabel ini dapat dilihat pada gambar seperti berikut ini:

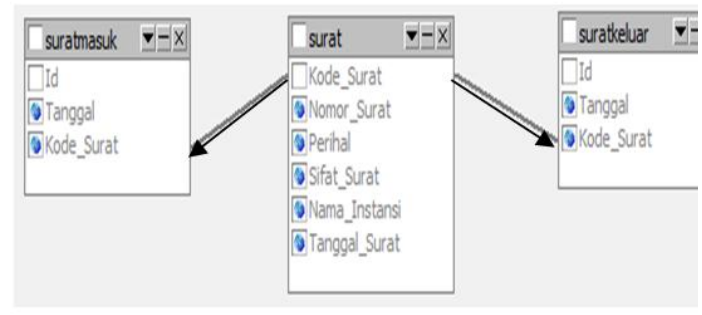

\section{Rancangan Logika Program}

1. Flow Chart Menu Log in

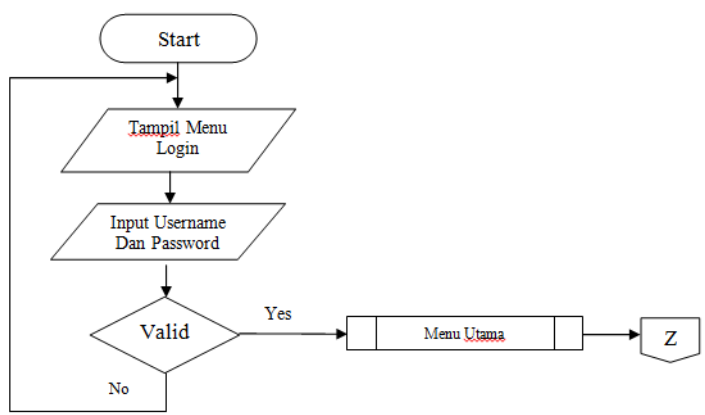

Keterangan :

1. Menjalankan aplikasi login

2. Menu login tampil

3. Inputkan username dan password

4. Jika valid maka tampilkan menu utama

5. Jika tidak valid kembali ke tampilan menu login

\section{Flowchart Menu Utama}

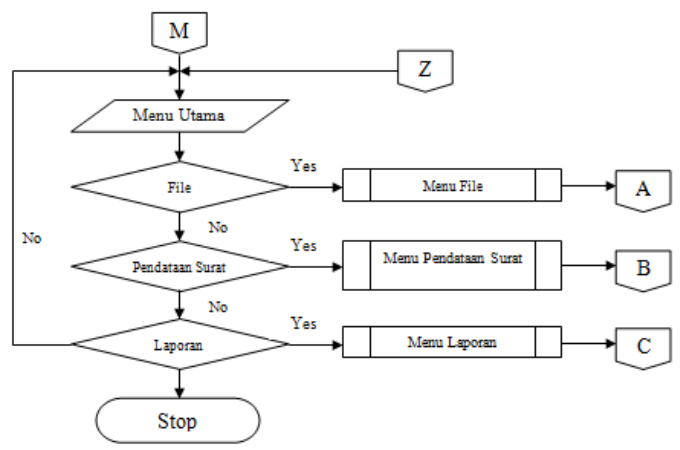

Keterangan :

1. Menjalankan aplikasi pendataan surat masuk dan surat kluar

2. Мепи utama tampil

3. Menu utama menampilkan menu File, proses atau laporan

4. Menu file berisikan tentang submenu surat, tamu hotel dan keluar 
5. Mепu proses berisikan tentang submenu pendataan surat

6. Мепи laporan berisikan tentang submenu laporan data surat, pendataan surat masuk, dan pendataan surat keluar.

7. Jika ingin keluar maka aplikasi akan berhenti

3. Flowchart

Submenu

File

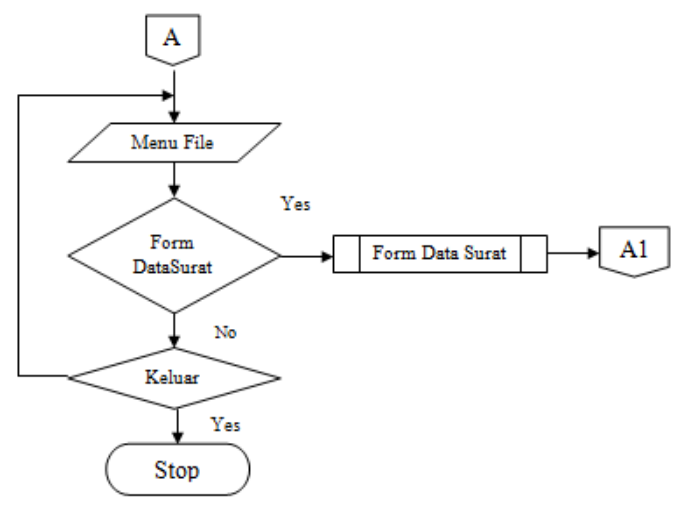

Keterangan :

1. Jika memilih menu file maka aplikasi akan menawarkan submenu kamar, tamu hotel atau keluar

2. Jika memilih submenu kamar, maka akan muncul form kamar

3. Jika memilih submenu tamu hotel, maka akan muncul form tamu hotel

4. Jika memilih submenu keluar, maka aplikasi akan berhenti
4. Flowchart Surat

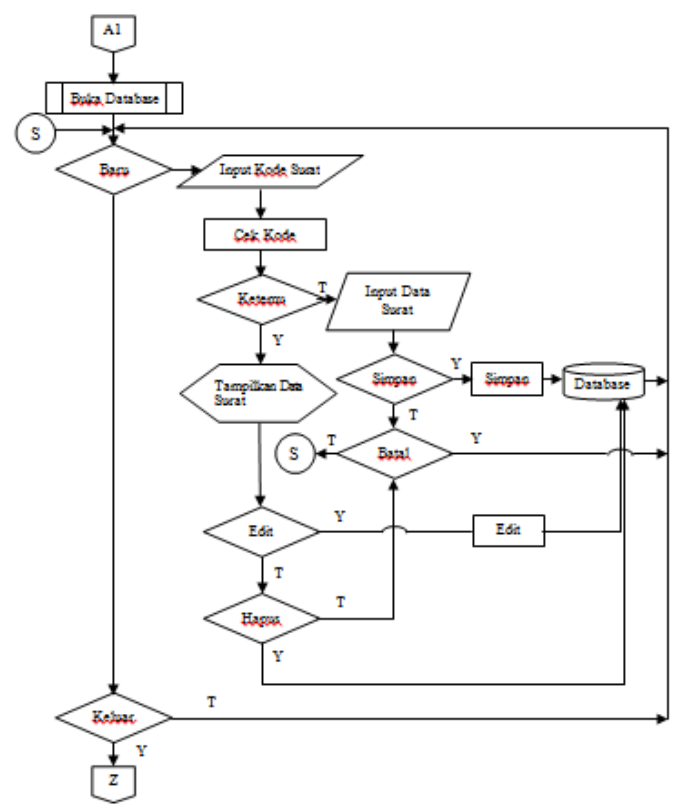

Keterangan:

1. Klik tombol baru untuk menambahkan record baru

2. Isikan form isian surat, jika ingin menyimpan maka data akan disimpan ke dalam database. Jika maka klik batal untuk membatalkan penyimpanan

3. Jika kode barang sebelumnya sudah di record maka program akan membrowse atau program akan menyediakan fasilitas edit, hapus dan batal.

4. Klik tombol edit Jika ingin mengedit data

5. Klik tombol hapus Jika ingin menghapus data

6. Klik batal jika ingin membatalkan proses yang sedang berlangsung

7. Klik tombol keluar untuk keluar dari form kamar.

JURSIMA

Jurnal Sistem Informasi dan Manajemen https://ejournal.giciku.ac.id/ STMIK GICI 
5. Flowchart Pendataan Surat Masuk

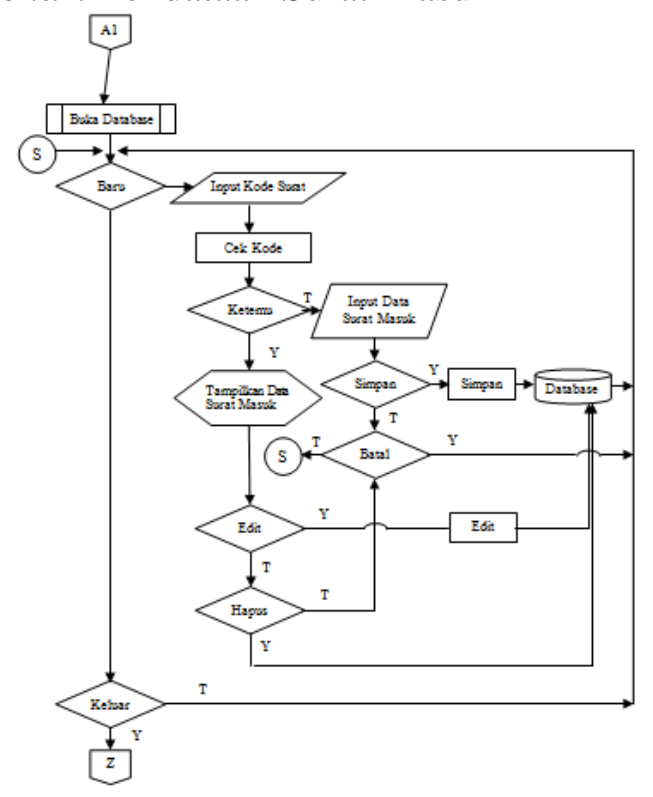

Keterangan:

1. Klik tombol baru untuk menambahkan record baru

2. Isikan form isian surat masuk, jika ingin menyimpan maka data akan disimpan ke dalam database. Jika maka klik batal untuk membatalkan penyimpanan

3. Jika kode surat masuk sebelumnya sudah di record maka program akan membrowse atau program akan menyediakan fasilitas edit, hapus dan batal.

4. Klik tombol edit Jika ingin mengedit data

5. Klik tombol hapus Jika ingin menghapus data

6. Klik batal jika ingin membatalkan proses yang sedang berlangsung

7. Klik tombol keluar untuk keluar dari form surat masuk
Flowchart Pendataan Surat Keluar

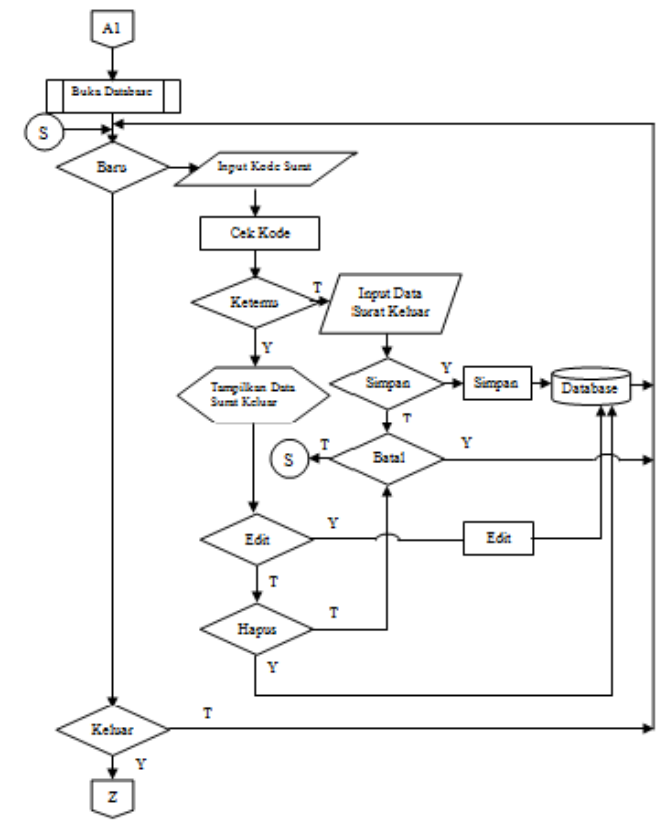

Keterangan :

1. Klik tombol baru untuk menambahkan record baru

2. Isikan form isian pemesanan, jika ingin menyimpan maka data akan disimpan ke dalam database. Jika maka klik batal untuk membatalkan penyimpanan

3. Jika kode pendataan surat keluar sebelumnya sudah di record maka program akan membrowse atau program akan menyediakan fasilitas edit, hapus dan batal.

4. Klik tombol edit Jika ingin mengedit data

5. Klik tombol hapus Jika ingin menghapus data

6. Klik batal jika ingin membatalkan proses yang sedang berlangsung

7. Klik tombol keluar untuk keluar dari form pendataan surat keluar. 
ISSN 2338-1523

E-ISSN 2541-576X

Volume 5 No. 1

Mei 2017

Simarmata Janner dan Paryudi Iman, Basis

Data, 2005

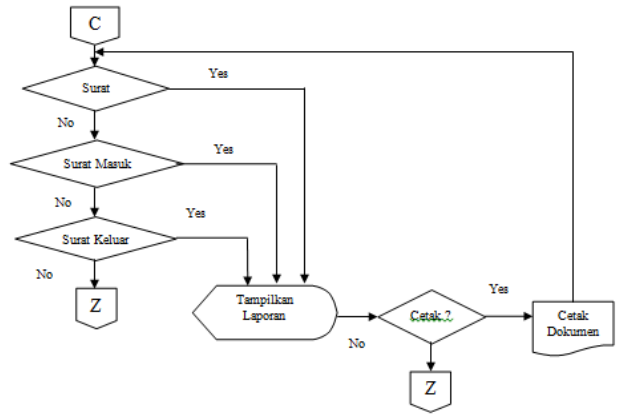

Tata Sutabri (2012;6) Analisis Sistem Informasi

Keterangan:

1. Klik salah satu submenu laporan

2. Jika sudah memilih salah satu laporan maka aplikasi akan menampilkan laporan

3. Jika ingin dicetak maka dokumen akan terprint sesuai dengan divice yang ada

4. Jika tidak maka akan kembali ke menu utama.

\section{UCAPAN TERIMA KASIH}

Penulis mengucapkan terima kasih kepada berbagai pihak terutama Ketua Sekolah Tinggi Manajemen Informatika dan Komputer GICI yang telah membantu penulis menyelesaikan penulisan ini.

\section{DAFTAR PUSTAKA}

Hendrayudi,Dasar-Dasar Pemograman Microsoft Visual Basic 2008,2011

Iman Paryudi (2005;1) Basis Data

Jogiyanto, Pengenalan Komputer, 2001.
Junindar, Panduan Lengkap Menjadi Programmer Membuat Aplikasi Penjualan Menggunakan VB.Net, 2008

